Aleksandar Vekić, Angela Fajsi, Jelena Borocki

University of Novi Sad, Faculty of Technical Science,

Department of Industrial Engineering and Management, Serbia

\title{
Development of Entrepreneurial Ecosystem through University's New Companies
}

DOI: 10.7595/management.fon.2019.0012

Abstract:

Research Question: This paper explores the potential of new start-ups and spin-offs within the university capacity and their impact on the process of creating an entrepreneurial ecosystem. Motivation: The research presented in this paper is motivated by the desire to analyse the role of university in entrepreneurial ecosystem based on the real case of the University of Novi Sad. An insight into relevant literature sources revealed that there exists a large influence of university's new companies in developing the entire business environment and business sustainability. This example could be relevant to similar universities in the other developing countries, because current literature covers only examples from developed countries. One of this is a research paper conducted by the Stanford University under the name "An analysis of the entrepreneurial activity of the Stanford community over 50 years". Idea: The main idea is to present the importance of University's new companies in creating an entrepreneurial ecosystem, and their impact on the creation of economic activity and sustainable development. Data: This research includes economic activity data of business entities at the University of Novi Sad. This paper presents data on new companies within the University of Novi Sad in the period 1990-2015 which were available, as well as data on companies in the territory of the Republic of Serbia, Vojvodina region and the City of Novi Sad. In this analysis, 123 companies from the University of Novi Sad were included. Tools: In this paper comparative statistics was used based on collected data of the total number of companies and the number of employees according to company's size and geographical location. For the purpose of this research, we used interactive internet portals Trading Economics and IvanStat. Findings: According to the analysis, the University of Novi Sad is a prominent example of the establishment and operation of new companies founded within it. The percentage of companies that have survived in the observed period is high and it is approximately $63 \%$. Contribution: This paper gives us an overview of newly founded companies (start-ups and spin-offs) within the University of Novi Sad, especially focusing on economic activity and creating conditions for sustainable development.

Keywords: entrepreneurial ecosystem, innovation, start-up, spin-off, development, the University of Novi Sad

JEL Classification: M13, M15, O30, F63, L26

\section{Introduction}

Success of entrepreneurial ventures depends on the quality of entrepreneurial idea and the ability of entrepreneurs to realize it. Entrepreneurship is encouraged in almost all modern societies in many ways (through a large number of various entrepreneurship promotion programmes) and through the engagement of numerous institutions (different forms, ownership and structures). All programs are defined in the direction of creating such an environment in which entrepreneurship will be accepted and launching numerous entrepreneurial ventures, with the aim of achieving economic growth, solving the unemployment problem and raising the level of competitiveness. Establishment and development of an effective environment, that will promote entrepreneurial behaviour and provide knowledge and technology transfer on the market, is a significant challenge for organizations that operate in a dynamic business environment. This type of environment is recognized as an "entrepreneurial ecosystem".

Entrepreneurial ecosystem is a term that has become particularly interesting in the past few years. It can be viewed from a business, academic and policy points of view. Numerous definitions appear from prominent 
authors such as: (Ács et al., 2014) who have suggested that the entrepreneurial ecosystem refers to a wide range of needs of new ventures during the early stages of their life cycle; Isenberg (2010) - who has set up a very famous graphical presentation of entrepreneurial ecosystems; Vogel (2013a) - who created the entrepreneurial ecosystem index of different levels; Spigel $(2017)$ - who presented the criteria for determining the diversity of entrepreneurial ecosystems from business, innovation, clusters, industrial areas and other similar terms. As authors (Yan \& Guan, 2018) state: "Entrepreneurship ecosystem provides access to finance, education and R\&D transfer, government policies and programmes, as well as physical and professional infrastructure". Some authors, such as Ritala \& Almpanopoulou (2017), explain in detail the origin of the ecosystem itself, analyzing numerous sources of literature, trying to simplify different ecosystems that have become popular.

Today, the role of the university is vastly changed - from the exclusive role of education and research activities, to the role of institutions which can influence the economic growth of the region. Therefore, this potential puts them in the position of key actors in the entrepreneurial ecosystem. Also, entrepreneurial education of students, incentives to create entrepreneurial ventures and employees at universities and students, change the position of universities (Mazzarol et.al, 2016).

Academic entrepreneurship depends not only on the conditions in the external environment (which are expressed through intensive support to entrepreneurship), but also from the personal characteristics of the individual (Clarysse et al., 2011). On the other hand, universities are facing problems of commercialization of new knowledge, technologies and scientific and research results. Indicators of entrepreneurial orientation of universities can be directed to different levels: the level of an individual and/or organization, in line with the adopted indicators. One of the indicators is the number of newly founded companies, that is, spin-offs and start-ups.

Spin-offs can be defined as a "range of important functions, including a vehicle for technology transfer and technology commercialization, a way to produce direct income for universities, a source of employment, a way to strengthen the relationships with the local business community and a way to contribute to restructuring regional economies" (Pérez \& Sánchez, 2003; Van Geenhuizen \& Soetanto, 2009).

According to Reis, a start-up is "a human institution designed to deliver a new product or service under conditions of extreme uncertainty" (Reis, 2014). A start-up can be defined as a "temporary organization designed to search for a repeatable and scalable business model“ (Blank, 2013).

We also see a need for creating a distinction between two sub-categories of entrepreneurs. "The first category basically fosters an idea of entrepreneurship and creates a new firm or organisation based on that idea. The second category fosters an idea within an existing workplace, related to activities there, and takes this idea out of the workplace to start a new firm or organisation on their own, sometimes with formal or informal backing from their previous workplace". We label the first sub-category "independent entrepreneurs" and the second is "spin-off entrepreneurs" (Bager et al., 2010).

University spin-offs and start-ups receive the necessary resources from the university: access to research facilities, temporary accommodation and knowledge on management, patenting, manufacturing and practical issues (Carnesku \& Dungan, 2015). Universities usually have a good reputation in the society; academic entrepreneurs can lend credibility to their ventures by communicating to their contacts about their affiliation (Borges \& Filon, 2013). Entrepreneurial ventures are focused on conquering the market and making a profit through innovative activities. Spin-off companies imply that their founder has the support of the parent institution (as an intra-entrepreneur) in a formal or non-formal form, and the motive of establishing a company is the result of the need to commercialize knowledge or acquire new knowledge of technology. Spin-off companies are the result of entrepreneurship at the university (Rassmunsen \& Wright, 2015)

The purpose of this paper is to show the most important effects of establishment and promotion of an entrepreneurial ecosystem through university spin-off and start-up companies. Implications of basic economic indicators which are connected with the entrepreneurial environment of the University of Novi Sad will be shown in this paper.

This paper is organized in three chapters. The first chapter is an introduction and includes general definitions and explanations of terms related to this research. In the second chapter, literature review on the topic of university role within entrepreneurial ecosystem is presented. This chapter also covers university spin-offs and start-ups, their role and importance in the process of creation of an entrepreneurial ecosystem. Following this, in the third chapter, the example of University of Novi Sad is shown as a highly developed 
entrepreneurial university, in terms of founding and developing start-up and spin-off companies. Considering this, authors reviewed effects of entrepreneurial environment to economic development of one country and/or region and made implications for further research relevant to this topic.

\section{Literature Review}

Fostering entrepreneurship has become one of the most important elements of economic development in countries and regions around the world. A social-economic environment needs to be created or adapted to foster and affect entrepreneurship and promote creation of effective entrepreneurial ecosystem. An entrepreneurial ecosystem can be defined as "set of various actors within geographic region that influence creation and development of a group of stakeholders with an aim to generate a new venture creation over time" (Cohen, 2006).

An entrepreneurial ecosystem is a unique entity, in which enterprises and their entrepreneurial activity play a crucial role. Understanding and interpreting entrepreneurial activity and the number of enterprises is of great importance for defining further development strategies. Entrepreneurial activity is the enterprising human action in pursuit of the generation of value, through the creation or expansion of economic activity, by identifying and exploiting new products, processes or markets (Ahmad \& Seymour, 2008). The definitions recognise that many business entities can attempt to instill an entrepreneurial spirit in their employees and encourage them to be creative and innovative.

According to Isenberg (2010), an entrepreneurial ecosystem can be seen as a "collective vision of a group of stakeholders committed to the promotion of entrepreneurship, creating an ecosystem to actualize their vision". Isenberg defined a model of an ecosystem that consists of thirteen factors, which are shown in the figure below:

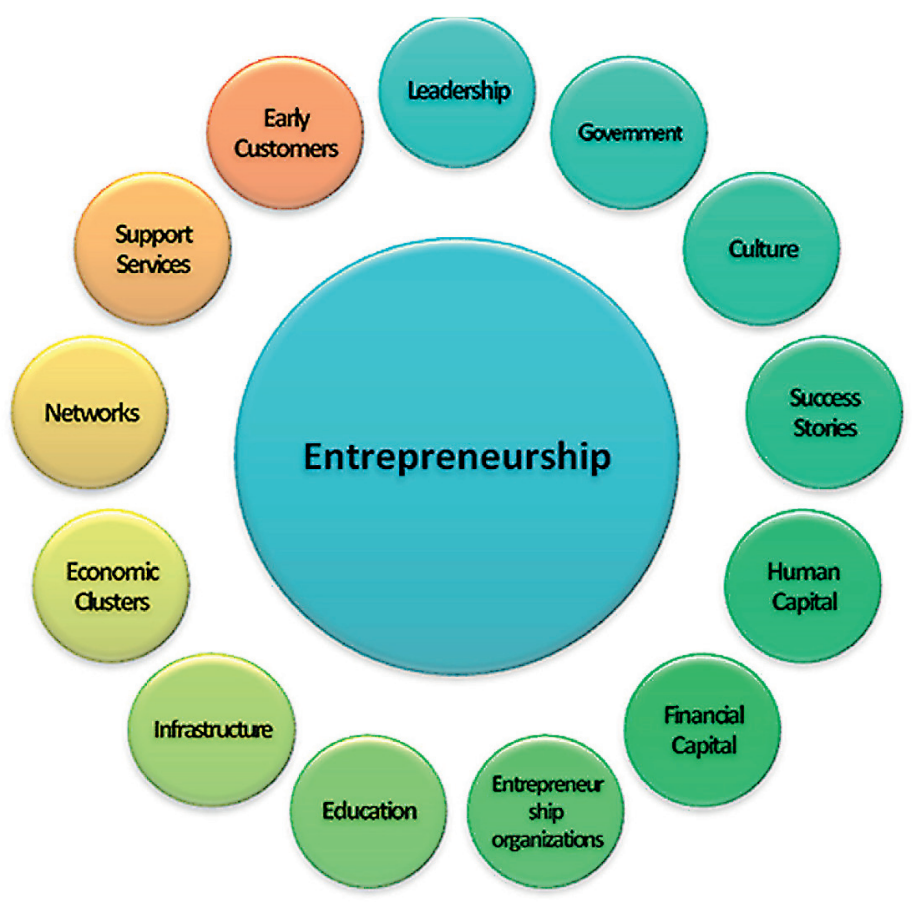

Figure 1. Thirteen factors of entrepreneurial ecosystem model (Isenberg, 2010)

Figure 1 shows factors that promote and foster entrepreneurship in a particular region or country. Each factor has its own role and importance, depending on the level of ecosystem development. Mason \& Brown (2013) define three main ecosystem groups, as follows:

- Entrepreneurial organizations - firms, venture capitalists, business angels, banks;

- Institutions - universities, public sector agencies, financial bodies; and

- Entrepreneurial processes - the business birth rate, numbers of high growth firms, number of serial entrepreneurs, levels of entrepreneurial ambition. 
Isenberg (2010) defines four main groups of stakeholders in entrepreneurial ecosystem: Government, Educational Institutions, Financial Institutions, Media and Network. The explanation of the term entrepreneurial ecosystem requires an analysis of its structure and all relations between key entities.

Entrepreneurial ecosystems cannot arise if the conditions of the external environment are not met: industry conditions, markets for new technologies, the existence of business incubators, but above all - an established and highly regarded knowledge base that employs a significant number of scientists and engineers (Mason \& Brown, 2013). An analysis of entrepreneurial ecosystems can include an analysis of its structure, relationships between key entities, performance criteria, development phases, etc. Thus, Spigel (2017) maintains that ecosystems represent more of a conceptual umbrella encompassing a variety of different perspectives on the geography of entrepreneurship, rather than a coherent theory about the emergence of sustainable communities of technology entrepreneurs. He emphasizes that "there is also a need for a dynamic perspective that seeks to understand how the structure and influence of ecosystems change over time as a response to both external economic and social shocks, as well as to internal changes, such as entrepreneurial success or concerted philanthropic or organizational efforts of a few "ecosystem entrepreneurs." At the same time, researchers must develop metrics that can be used to identify the presence of ecosystem attributes." Also, this author believes that an entrepreneurial ecosystem can arise from any entity. Regardless of the initial differences, both authors emphasize the importance of feedback and point to the fact that this is a dynamic mechanism.

Mack \& Mayer (2016) have upgraded the existing framework by explaining the stages in the development of entrepreneurial ecosystems, emphasizing that not all elements identified by Isenberg were equally important at each stage of development. These authors determine certain differences between entrepreneurial ecosystems and clusters, i.e., innovation systems, industrial areas. Similarly, a group of authors define the differences between the innovation ecosystem and others ecosystems (Oh et al, 2016). Brown \& Mason (2017) also propose a typology of ecosystems, but in two instead of four stages, as defined by Cukier et al. (2016). Stam and Spigel differ considerably in their theoretical assumptions about the entrepreneurial ecosystem: Stam believes that the components of the entrepreneurial ecosystem can be classified into two categories: framework and systematic conditions (Stam, 2015). He believes that success of entrepreneurial ecosystem depends on the components and relations between them. This author also claims the importance of entrepreneurial ecosystem, only regarded as a result of the system, but the role of entrepreneurs in creating such a system is also significant. Once an entrepreneurial ecosystem is established, measurement of its effectiveness would be desirable (as components and as a whole) in order to make certain improvements in future activities (Vogel, 2013b).

The explanation of an entrepreneurial ecosystem should not be transformed into an explanation of individual examples of this term, without explaining the theoretical framework in order to better understand the process of the emergence and the level of influence of the important actors of the entrepreneurial ecosystem. Dynamics of changes in the external environment also affects the entrepreneurial ecosystem. This is completely in line with the claims of (Kortelainen \& Järvi, 2014) who consider that knowledge in the area of entrepreneurial ecosystems rely mainly on qualitative studies, while the number of quantitative studies is significantly lower. Considering the development speed of cloudiness and the level of significance, it is expected that the situation will change relatively quickly.

Educational institutions have realized the strategic role of their research potentials and their ability to create and disseminate knowledge and skills. For that reason, universities are identified as main stakeholders in the process of fostering and promoting entrepreneurship. The role of the university in the process of creation anentrepreneurial ecosystem was explained in research paper by numerous authors (Clark, 2004; Kingma, 2014; Rice, Fetters \& Green, 2014; Fernandez, Jimenez \& Cuadrado, 2015; Schaeffer \& Matt, 2016; Hayter, 2016; Raagmaa \& Keerberg, 2017), and the author Malecki (2018) states that in his work. It is also important to explain the anatomy of the entrepreneurial university, i.e., that the entrepreneurial university model can be expressed in four inter-related propositions: interaction, interdependence, hybridization and reciprocity, which Etkowitz (2013) has determined in his work. Nowadays, educational institutions, especially universities are encouraged to become more entrepreneurial through greater commercialization of knowledge and innovations. Development and maintenance of an effective entrepreneurial environment lead to better economic performances and a more productive society as well. In that respect, in the following sub-chapter the role of academic spin-offs and start-ups in the development and promotion of entrepreneurial environment will be shown. 


\subsection{Role of university in the entrepreneurial ecosystem: spin-off and start-up companies}

Universities and public authorities should be advised to intensify their activities to foster and promote entrepreneurship, especially among young people. Such kind of activities leads directly to the creation of a culture of academic entrepreneurship (Luthje \& Franke, 2003). The most important entities of academic entrepreneurship are spin-off and start-up companies.

As the authors Rasmussen \& Wright (2015) argue, universities should set up new venture creation at the top of their list of priorities. The reasons are as follows: university knowledge, through new technologies, has a direct impact on economic growth; newly founded companies can act as technology transfer mechanisms that will tackle the existing knowledge in the application. The authors also consider that the newly founded companies play an important role in the economic and technological progress of other newly founded companies. This is in line with the claims that an increasing number of start-ups directly lead to the strengthening of the economy in one country or particular regions. Start-ups are designed to grow fast (Mata et al., 1995), hence, they could have a significant impact on the development of the economy in short term. It is noticeable, as the authors (Soetanto \& Geenhuizen, 2015) claim, that a small number of research works refer to the analysis of relations between the spin-off companies with the parent university and other institutions, and their ability to attract certain finances for innovation activities. Also, it would be useful to know which entrepreneurial competencies are needed to create spin-off ventures, professionals who can provide such competencies, and in that sense how such competencies are developed. Authors (Rasmussen et al., 2011) have described that process in detail in their work. Universities are complex organizations, with a large number of employees and special dynamics, and their activities can affect the results and effect of spin-offs at various levels at different stages (Rasmussen \& Wright, 2015).

The university spin-offs transfer technology from their parent organization in the first phase, then they transfer technology to their clients. Developing an effective network of various stakeholders is a key challenge for successful functioning of spin-offs (Todorovic et al., 2011). This network brings together not only academically-oriented stakeholders, but also ones who are primarily market-oriented. (Pérez \& Sánchez, 2003). The creation of successful spin-offs requires various types of resources such as knowledge, finances, organizational assets, social capital and intellectual property (Landry et al., 2006), (Steffensen et al., 2000) highlighted critical success factors for academic spin-offs, such as risk taking, opportunity identification and risk mobilization.

The technology transfer is based on the network capability that enables companies and other participants to build strong relationships. On the participant's side, relationships are important means of sharing resources, knowledge, expertise, software, equipment, etc. (Perez \& Sanchez, 2003). However, these relations are also important from the point of view of economic development of some region and/or country. The existence of spin-offs with important and purposeful connections increase productivity of their actors (e.g., research institutions, customers, legal authorities) (Walter et al., 2006). Spin-offs continuously seek to contribute to the region's and the country's economic development (Mian, 1997), and for that reason, they are recognized as important business support mechanisms.

When it comes to start-up companies, it can be said that they are unpredictable organizations that are primarily oriented towards research of business opportunities. In the early stage of start-up development, educational and research institutions have an important role in strengthening their capacities and fostering their further development. Likewise, the government and public authorities have a significant role in start-up development through defining policies and strategies that support their growth and enable their transformation from start-ups to SMEs (Laso, 2016). It is also very difficult to estimate how universities can best assist the development of high-growth technology ventures - primarily because such companies are as diverse as universities, and the context in which they operate is complex (Rasmussen \& Wright, 2015).

Spin-offs and start-ups are related to economic growth and increasing the number of employees. The promotion of the entrepreneurial vision via spin-off and start-up companies could motivate researchers and scientists for a higher level of commercialization of research knowledge. In the past years, the analyses of successful spin-off companies have been presented in the works of numerous authors (Colombo \& Piva, 2012; Guerrero \& Urbano, 2014; Huynha, et al., 2017) where, as a common denominator, there is a claim that universities have a strong influence on the entrepreneurial behaviour of these companies. Some authors (Huynha, et al., 2017) analyze the methods of measuring the performance of spin-off companies using certain measurement models. 


\section{Research Results}

By the University of Novi Sad turning to entrepreneurship activities and achieving flexibility in this direction, conditions have been created to support the establishment and development of start-up and spin-off companies, which in previous years was not the case. The university does not own these companies. These are individuals affiliated with the university and in the academic setting (Shane, 2004). The founders of the spin-offs and start-ups in general are students, graduates or academic staff (professors and assistants). Since academic spin-offs have a historical relationship with universities such as their professors previously guiding research work or former colleagues working on similar subjects, those ties could lead to a recommendation and intermediation to potential industrial partners or investors (Carnesku \& Dungan, 2015). The first company of this type within the University of Novi Sad was founded in 1990. The infrastructure that would support establishing of this type of company did not exist at that time. After 20 years since the establishment of the first company within the University, the first supporting institutions were created in the form of business incubators, technology development centers, business hubs, and science and the technology park which is still under construction. During the period of 1990-2015, within the University of Novi Sad 123 new companies were established and these are the subject of analysis in this paper. In the last few years, thanks to the established entrepreneurial ecosystem, as well as numerous formal programs (subjects, studies) and informal programs (projects) for stimulating entrepreneurial behaviour, the number of spin-offs owned by students has increased. The Faculty of Technical Sciences Novi Sad, which is also the largest faculty within the University of Novi Sad, has a significant role in the process of creation of these companies. At the same time, at this faculty, entrepreneurship is being studied at all study levels, through 16 specially structured subjects within 9 different departments (Vekic et al., 2018). Relevant statistical data from different bases and official data from the University of Novi Sad have been used as a comparative indicator (Figure 2).

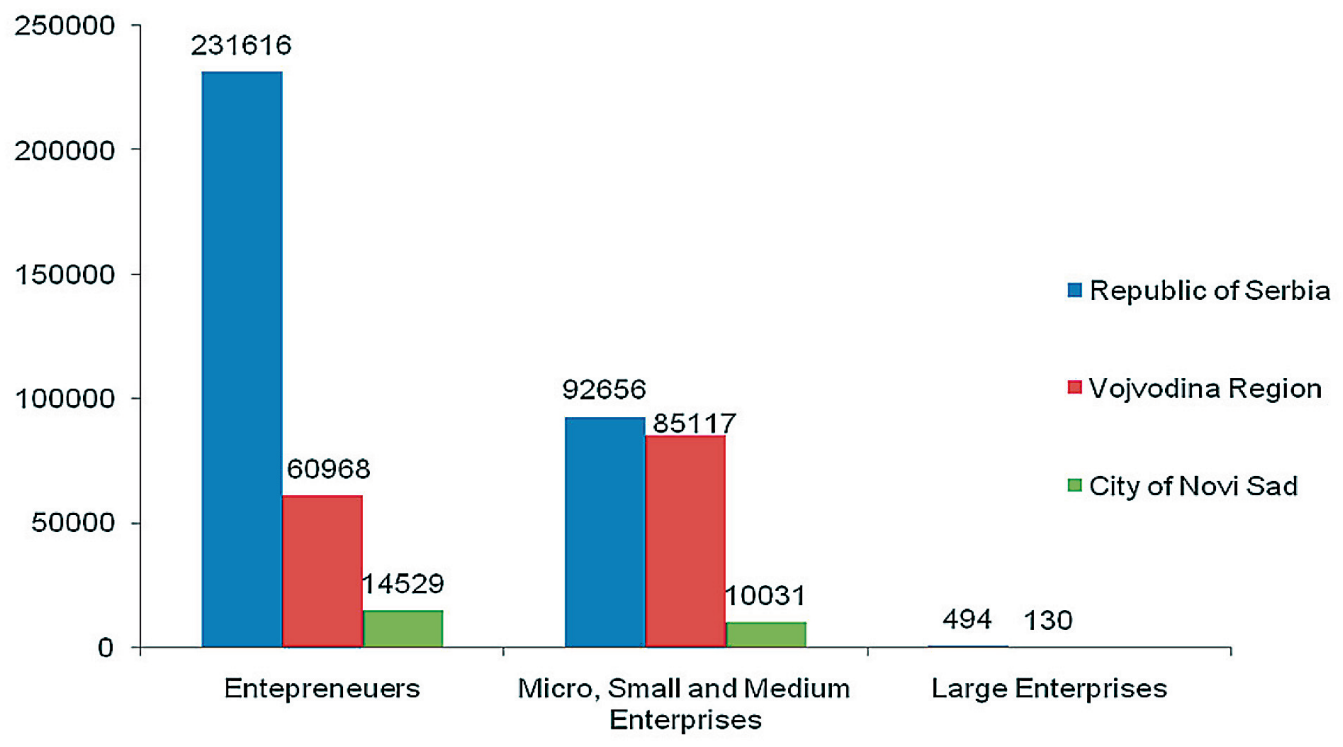

Figure 2: Number of enterprises by size in the Republic of Serbia, Vojvodina Region, and City of Novi Sad in $2014^{22}$ According to the available reports, 2014 was the last year in which was possible to calculate the numbe

(Source: Authors' calculation according to data from the Statistical Office of the Republic of Serbia, 2018)

These data show that $99.84 \%$ of total enterprises in the Republic of Serbia are entrepreneurs and micro, small and medium enterprises. These results do not deviate very much from the European average. If we look at the region of Vojvodina, that percentage is $99.9 \%$ of the total number of business subjects. The used database did not find the exact number of large companies in the City of Novi Sad. Business entities from the City of Novi Sad make $7.56 \%$ of the total number of business subjects in the Republic of Serbia, and $16.57 \%$ of the total business subject in the Vojvodina region. 


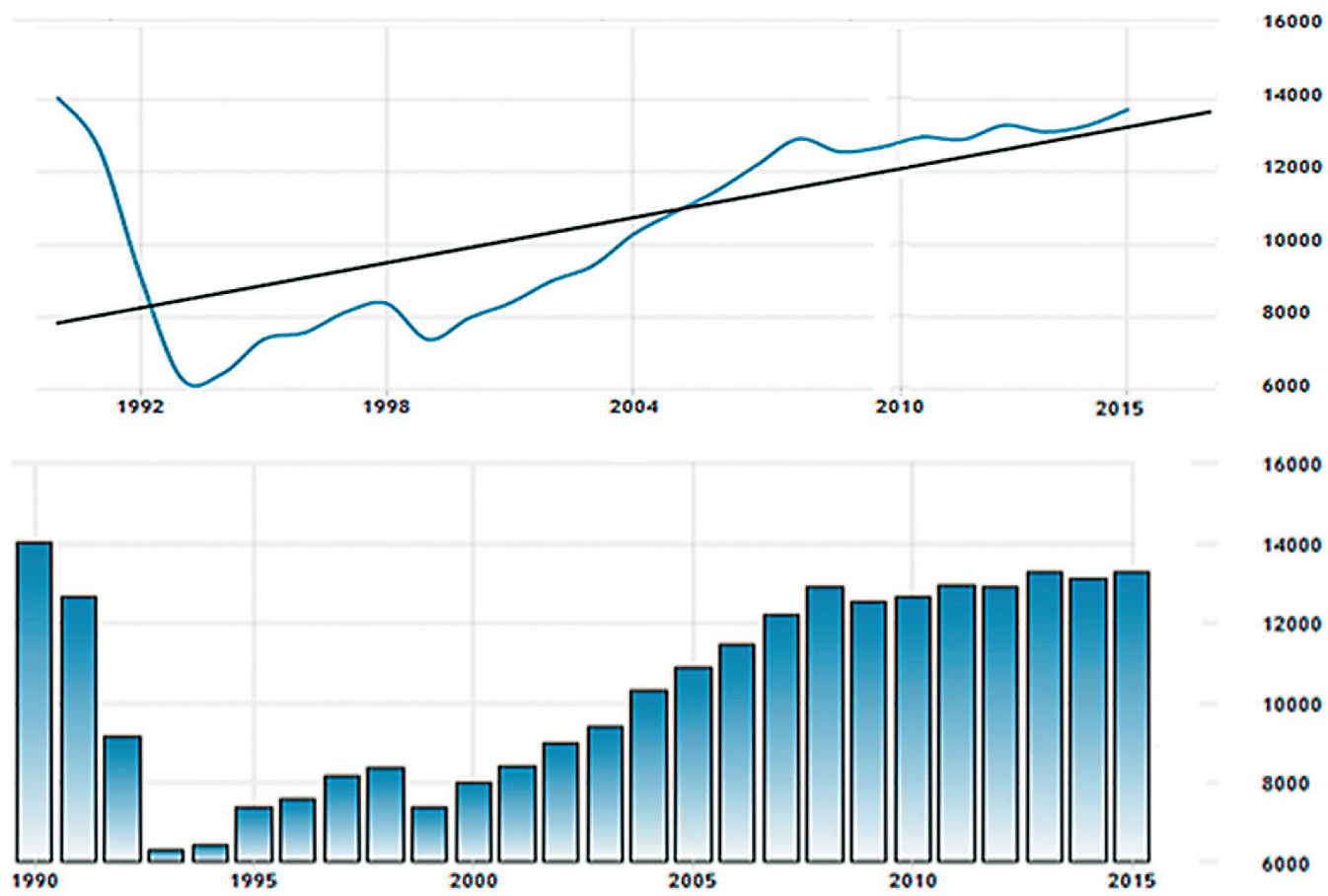

Figure 3. GDP growth in the Republic of Serbia in the period 1990 - 2015 in USD

(Trading Economics.com; IvanStat.com, 2018)

The observed phenomenon can also be related to the movement of gross domestic product, as a basic indicator of economic activity in one country (Figure 3). With economic growth, there is also increased allocation of funds in all areas of economy and society, as well as in the allocation of funds for launching and supporting new business entities, where the start-up and spin-off companies certainly play an important role. The trend line in the GDP of the Republic of Serbia has an oscillatory movement (last 10 years), with an observed increased trend in the last 3 years. In the same period, observing our sample, we can see a growing number of companies that have been established as a start-up or a spin-off company (58 new founded companies or $47.15 \%$ ) of all new founded companies within the University of Novi Sad. This can be an indicator that shows a strong development of the entrepreneurial ecosystem, which should be the leverage of fast economy development and all business entities within. There is also a positive impact on other economic indicators such as employment growth, taxation, per capita income, etc. The unemployment rate has decreased, especially in the last 5 years (2014-2018) from 19.22\% to 11.3\% (Statista.com, 2018). The total number of employees in these companies has reached almost 3000. Also, entrepreneurial ecosystems could enable a faster pace of technological progress and the introduction of new technologies, development of human resources and their mobility.

The development of an entrepreneurial ecosystem is the mission of all modern universities. Establishing entrepreneurial ecosystems with the support of the university should create a basis for further development of the university, and its research activities. In this way, sustainability and development are established according to modern trends, and the University of Novi Sad follows this direction. In (Table 1) basic indicators about the University of Novi Sad are presented.

Table 1: Basic indicators of theUniversity of Novi Sad

\begin{tabular}{|l|c|}
\hline \multicolumn{2}{|c|}{ University of Novi Sad - Review } \\
\hline Number of faculties & 14 \\
\hline Number of accredited study programs & around 400 \\
\hline Number of students & more than 50.000 \\
\hline Number of employees & more than 5.000 \\
\hline Number of Scientific Institutes & 17 \\
\hline Number of University Centers & 250 \\
\hline Number of Scientific Laboratories & 126 \\
\hline Number of projects (up to 2016) & 127 \\
\hline Number of partner and coordinating international projects & \\
\hline
\end{tabular}


Orientation of universities to support creation of entrepreneurial ventures and creation of entrepreneurial ecosystem is certainly a significant characteristic. This requires a high level of engagement of all available resources that one university has, as well as a longer period of time for the establishment of stable bases, which should lead to the sustainability of the entrepreneurial ecosystem.

By strengthening its own capacities, but also by developing the economy as a whole, the University is able to create entrepreneurial environment and to enable an intensive transfer of academic ideas into marketoriented ventures. In this case, a 25-year period was taken, in which there were very large changes in the society, but also on the global level.

The transition to the market economy, higher usage of the Internet in business, the strengthening of academic potentials, development of a democratic society, and the orientation towards wider domestic, regional, European and world market have all led to a change in the way of entrepreneurial thinking.The occurrence of start-up and spin-off companies is an indispensable part of every developed society, if we take into account the macro level, but also every individual participant in the entrepreneurial ecosystem, if we observe the micro level.

According to the analysis of our sample, it can be noticed that about 78 companies out of 123 are still active, which indicates that success rate of such ventures at the observed University is around $63 \%$.

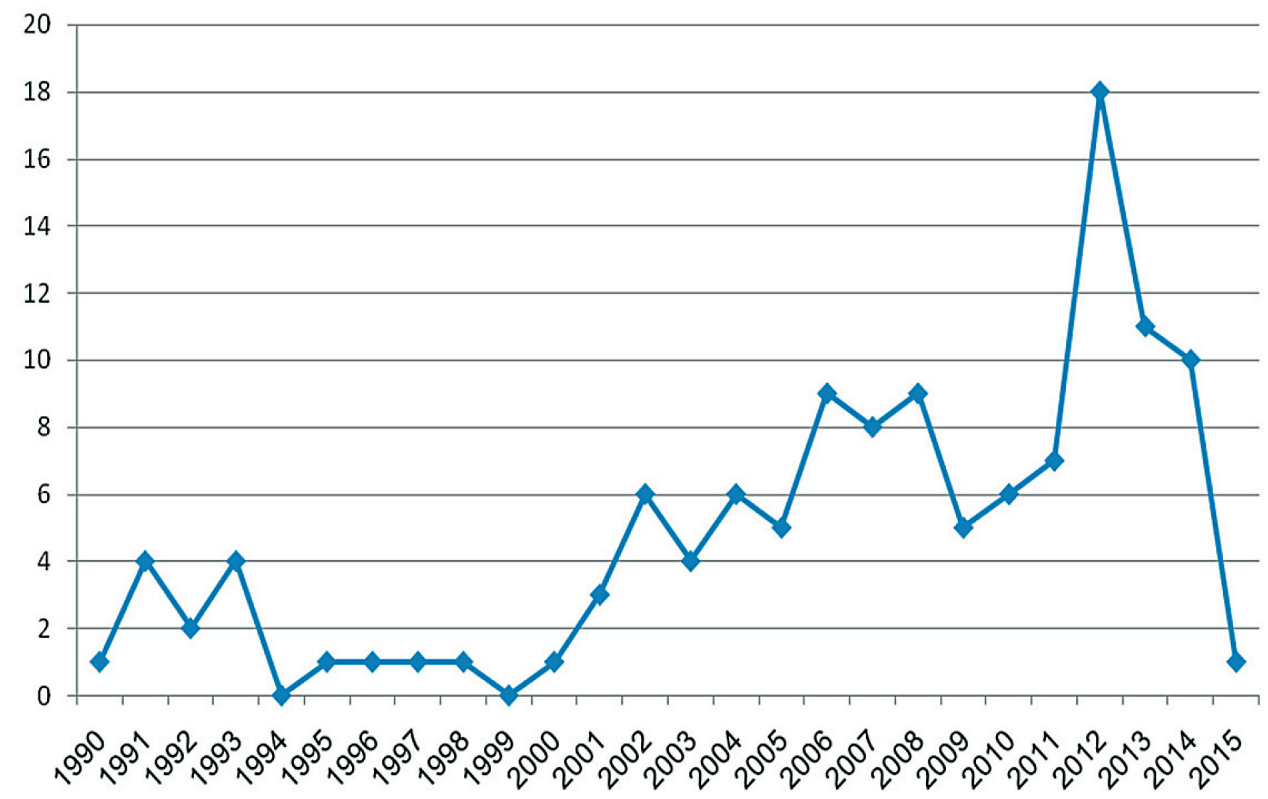

Figure 4. The number of founded start-up and spin-off companies in the period 1990-2015 at the University of Novi Sad (University of Novi Sad, 2018)

The largest number of start-up and spin-off companies at the observed University was founded in the last 10 years (Figure 4). This has certainly contributed to the current trends, the increasing openness of universities to launch such ventures, and supporting the building of a unique entrepreneurial ecosystem. The largest number of these companies was established in 2012, more than 18, while a small number of them were established at the beginning of the observed period. The causes for a small number of founders should be sought in a very poor economic environment, the lack of market economy as well as the consequences of wars and the period of sanctions. A possible explanation of this phenomenon may also be an insufficient understanding of the importance of establishing such types of business entities in the economy. A slight activity in triggering this type of venture was observed during the period of major economic crisis from 2008. The need for a rapid development can be one of the reasons for the increase in the number of newly established companies, through raising awareness of the importance of starting one's own business and the opportunities that this kind of activity brings. There is also a growing support from relevant stakeholders in the economy and entrepreneurial ecosystem, among which are certain universities. Possibilities for applying for new sources of financing, both in the country and abroad, especially within European funds, have increased. 


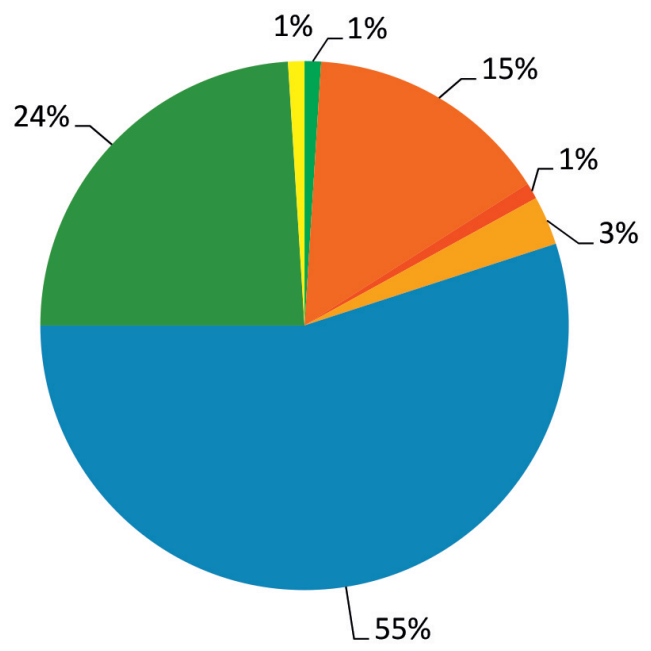

\begin{tabular}{|l|}
\hline Agriculture, Forestry and \\
Fischeries \\
Manufacturing industry \\
Civil engineering \\
Trade \\
ICT \\
Professional, scientific, technical \\
and innovation activities \\
Art, entertainment and \\
recreation
\end{tabular}

Figure 5. Start-up and spin-off companies at the University of Novi Sad by industry division (University of Novi Sad, 2018)

\begin{abstract}
The largest number of observed companies belongs to the field of information and communication technologies; in the second place are professional, scientific, innovative and technical activities, and in the third place are companies in the field of manufacturing industry (Figure 5). The total number of employees within these companies in 2015 was 2201 , which represents $1.75 \%$ of the total number of employees in the City of Novi Sad. Nowadays, some of start-up and spin-off companies are large enterprises, with more than 250 employees. This has a very beneficial effect on both local and national economy. Significant development of entrepreneurial activity and a number of different types of entities involving start-up and spin-off companies, based on the foundations established at the university, enabled the participation of other participants in the creation of entrepreneurial ecosystems. Their contribution to the development of this system is of great importance and by their active participation in system constructing, they influence its quality and strengthening. Among these institutions and companies, which are part of entrepreneurial ecosystem, exists a high level of interdependence. Some of the most important institutions in the functioning of entrepreneurial ecosystems at the city and province levels are: Business incubators (in Novi Sad, Subotica, Senta, Zrenjanin), StartitCentar Novi Sad, iDEA Lab, Vojvodina Chamber of Commerce, The Regional Development Agency Backa, different clusters, Provincial government and a large number of other Province and City institutions. The Science and Technology Park Novi Sad is currently under construction and it will certainly contribute to the further development of the presented entrepreneurial ecosystem.
\end{abstract}

\title{
Conclusion
}

The development of an entrepreneurial ecosystem has great importance at all levels: local, province and national. Entrepreneurial vision should be promoted and fostered in both market-oriented and academic-oriented environment. Observing the start-up and spin-off companies at the University of Novi Sad, and basic indicators of their economic activity, we can notice the positive data in terms of the number of employees and total income. The number of employees in these types of companies amounts to almost 3000, with total income exceeding $€ 100$ mil (source: Serbian Business Registers Agency, 2018). This points to the possibility of allocating a higher level of funds for new investment cycles and raising the innovation and competitiveness of these companies. Considering the constant growth of the number of employees, it can be said that the largest investments are also realized in human resources in order to attract, develop and retain them. This research contains certain limitations-it should continue in more detail, by collecting new data and by applying certain methodologies for measuring the success of entrepreneurial ecosystems. The importance of university can be measured by its ability to stimulate and support entrepreneurial activity. It is necessary to create a stable environment and conditions that will lead to the development of an entrepreneurial ecosystem in all its aspects. This requires a high level of readiness for engagement and cooperation among all participants in an entrepreneurial ecosystem, in order to achieve set of goals.

The author Etzkowitz (2013) gives an explanation of anatomy of entrepreneurial university, describing the stages of academic involvement (three stages) in detail. These three stages are: (1) technology transfer (2) firm formation and (3) regional development signifies the transition from a research to an entrepreneurial university as the academic ideal. According to data obtained by the analysis of the University of Novi Sad, we can assume that the University of Novi Sad is in the second phase (with clearly defined support institutions - Technology Transfer Office, Incubator - and applied commercialization processes of research results). The next phase will include a proactive role of the University in the 
process of improving the region's innovative potential, through an even more intense cooperation with the economic actors of the region and official state institutions.

Without the support of official institutions in the region, the success of the entrepreneurial ecosystem would not be possible. Although, there are numerous examples in the analyses of successful existing entrepreneurial ecosystems, without a clear theoretical framework, these are not enough, since they explain only successful cases. Authors Clarysse et al. (2011) claim that establishing a process by a large number of spin-off companies is linked to the technology transfer office within the university, which in the case of the University of Novi Sad was not confirmed.

The failure rate for newly founded companies is very high within the University of Novi Sad, but the results are still better than in a large number of other successful examples. The extension of this research could include a more detailed analysis of factors that could affect the failure of spin-off companies, applying and/or creating a model for measuring the success of these companies. Also, it would be recommendable to analyze the role of the founders of spin-off and start-up companies - as the role of entrepreneurs is important for the entrepreneurial ecosystem. Also, it would be advisable to analyze the structure and other relevant elements of entrepreneurial ecosystems in developing countries and determine what differences exist regarding the developed countries.

According to the previous results, it is obvious that the University of Novi Sad is making tremendous efforts to permanently encourage the building of a strong and stable entrepreneurial ecosystem, which will play a major role in the economy of the whole country and beyond. This feature of the university leads to the strengthening of innovative potential and implementation of important projects from different fields. In the future, it is expected that the results of entrepreneurial activity within the University of Novi Sad will be more accessible, more measurable, and in that way more suitable for research, which will be another indicator of the strength and development which this entrepreneurial ecosystem has.

\section{Acknowledgements}

The authors acknowledge the financial support of the Ministry of Education and Science of the Republic of Serbia, within the Project No. 47005

\section{REFERENCES}

[1] Acs, Z.J., Autio, E., \& Szerb, L. (2014). National systems of entrepreneurship: Measurement issues and policy implications. Research Policy 2014, 43(3), pp.476-494.

[2] Ahmad, N., \& Seymour G. R. (2008). Statistics Directorate, OECD; Richard Seymour, The University of Sydney, Australia.

[3] Bager, T., Ottósson, H., \&Schøtt, T. (2010). Intrapreneurs, entrepreneurs and spin-off entrepreneurs: Similarities and differences, Paper to International Journal of Entrepreneurship and Small Business, 10 (3), pp. 339-358.

[4] Blank, S. (2013). "Why the Lean Start-Up Changes Everything. Harvard Business Review.

[5] Borges, C., \& Filon, L.J. ( 2013). Spin-off Process and the Developoment of Academic Entrepreneur's Social Capital, Journal of Technoogy Management \& Innovation, 8(1).

[6] Brown, R., \& Mason, C. (2017). Looking inside the spiky bits: A critical review and conceptualization of entrepreneurial ecosystems. Small Business Economics, 49, pp.11-30.

[7] Cernesku, L.M., \& Dungan, L.I. (2015). Spin-off. Theorethical Approach Overview, Procedia of Economics and Business Administration, ISSN: 2392-8174.

[8] Clark, B. R. (2004). Sustaining change in universities, a society for research into higher education. Open University Press.

[9] Clarysse. B., Tartari. V., \& Salter. M. (2011). The impact of entrepreneurial capacity, experience and organizational support on academic entrepreneurship, Research Policy, 40(8), pp.1084 -1093.

[10] Cohen, B. (2006). Sustainable valley entrepreneurial ecosystems. Business Strategy and the Environment, 15(1), pp.1-14.

[11] Colombo, M. G., \& Piva, E. (2012). Firms' genetic characteristics and competence - enlarging strategies: A comparison between academic and non-academic high-tech start-ups. Research Policy, 41(1), pp.7992.

[12] Cukier, D., Kon, F., \& Lyons, T. S. (2016). Software startup ecosystems evolution: the New York city case study. In Proceedings. Piscataway: IEEE. Retreived from: http://ccsl.ime.usp.br/startups/sites/ccsl.ime.usp.br.startups/files/newyork-ecosystem.pdf

[13] Etzkowitz, H. (2013). Anatomy of the entrepreneurial university, Social Science Information, 52(3), 2013, pp.486-511. DOI: 10.1177 / 0539018413485832.

[14] Fernandez Fernandez, M. T., Blanco Jimenez, F. J., \& Cuadrado Roura, J. R. (2015). Business incubation: Innovative services in an entrepreneurial ecosystem. Service Industries Journal, 35, pp.783-800. 
[15] Guerrero, M. \& Urbano, D. (2014). Academics' start-up intentions and knowledge filters: an individual perspective of the knowledge spillover theory of entrepreneurship. Small Business Economics, DOI: 10.1007/s11187-013-9526-4.

[16] Hayter, C. S. (2016). A trajectory of early stage spinoff success: The role of knowledge intermediaries within an entrepreneurial university ecosystem. Small Business Economics, 47, pp.633-656.

[17] Huynha. H., Patton. D., Arias-Arandab. D. \& Molina-Fernandez. L.M. (2017). University spin-off performance: Capabilities and networks of founding teams at the creation of fashions, Journal of Business Research 78, pp.10-22, Retrieved from: http://dx.doi.org/10.1016/j.jbusres.2017.04.015.

[18] Isenberg, D. (2010). The Big Idea: How to Start an Entrepreneurial Revolution. Harvard Business Review, 88(6), pp.41-50.

[19] IvanStat (2018). Serbia GDP. Retrieved from: http://www.ivanstat.com/en/gdp/rs.html.

[20] Kingma, B. (2014). Creating a dynamic campus-community entrepreneurial ecosystem: Key characteristics of success. In A. C.Corbett, D. Siegel, and J. A. Katz (Eds.), Advances in entrepreneurship, firm emergence and growth, Bingley: Emerald Group. (Vol. 16: Academic entrepreneurship: Creating an entrepreneurial ecosystem) (pp. 97-114).

[21] Kortelainen, S., \& Järvi, K. (2014). Ecosystems: systematic literature review and framework development. Paper presented at the ISPIM Conference Proceedings.

[22] Landry, R., Amara, N., \& Rherrad, I. (2006). Why are some university researchers more likely to create spin-offs than others? Evidence from Canadian universities. Research Policy, 35(10), pp.1599-1615.

[23] Laso, I. (2016). New role in the governments in the era of ICT start-ups. Retrieved from: http://news.itu.int/new-role-governments-era-ict-start-ups/.

[24] Luthje, C., \& Franke, N. (2003). The 'making' of an entrepreneur: testing a model of entrepreneurial intent among engineering students at MIT. R\&D Management, 33(2), pp.135-147.

[25] Mack, E., \& Mayer, H. (2016). The evolutionary dynamics of entrepreneurial ecosystems. Urban studies, 53(10), pp.2118-2133.

[26] Mazzarol, T., Battisti, M., \& Clark, D. (2016). The role of universities as catalysts within entrepreneurial ecosystem.

[27] Malecki, E.J. (2018). Entrepreneuership and Entrepreneurial ecosystems. Geography Compass 12(3), DOI: $10.1111 /$ gec3.12359.

[28] Mason, C., \& Brown, R. (2013). Entrepreneurial ecosystems and growth oriented entrepreneurship. Final Report to OECD, Paris, 30(1), pp.77-102.

[29] Mata, J., Portugal, P., \& Guimaraes, P. (1995). The survival of new plants: Start-up conditions and postentry evolution. International Journal of Industrial Organization, 13(4), pp.459-481.

[30] Mian, S. A. (1997). Assessing and managing the university technology business incubator: an integrative framework. Journal of business venturing, 12(4), pp.251-285.

[31] Oh, D.-S., Phillips, F., Park, S., \& Lee, E. (2016). Innovation ecosystems: A critical examination. Technovation, 54, pp. 1-6. DOI: 10.1016/j.technovation.2016.02.004i.

[32] Perez, M. P., \& Sánchez, A. M. (2003). The development of university spin-offs: early dynamics of technology transfer and networking. Technovation, 23(10), pp.823-831.

[33] Raagmaa, G., \& Keerberg, A. (2017). Regional higher education institutions in regional leadership and development. Regional Studies, 51, pp.260-272.

[34] Rasmussen, E., Mosey,S., \& Wright, M. (2011). The Evolution of Entrepreneurial Competences: A Longitudinal Study of the University Spin-Off Venture Emergence, Journal of Management Studies 48, pp.1314-1345, Blackwell Publishing Ltd and Society for the Advancement of Management Studies. DOI: 10.1111/j.1467-6486.2010.00995.x.

[35] Rassmussen, E., \& Wright, M. (2015). How can universities facilitate academic spin-offs? An entrepreneurial competency perspective. The Journal of Technology Transfer, Springer, Vol. 40, Issue 5, pp.782-799. DOI: 10.1007/s10961-014-9386-3

[36] Rice, M. P., Fetters, M. L., \& Greene, P. G. (2014). University-based entrepreneurship ecosystems: A global study of six educational institutions. International Journal of Entrepreneurship and Innovation Management, 18, pp. 481-501.

[37] Ries, E. (2014). Lean startup, Mate, Belgrade, Serbia.

[38] Ritala, P., \& Almpanopoulou, A. (2017). In defense of 'eco' in innovation ecosystem. Technovation 6061,pp.39-42, 0166-4972/Elsevier Ltd. DOI: 10.1016/ j.technovation.2017.01.004.

[39] Serbian Business Registers Agency (2018). Retrived from: http://www.apr.gov.rs/eng/Home.aspx

[40] Schaeffer, V., \& Matt, M. (2016). Development of academic entrepreneurship in a non mature context: The role of the university as a hub organisation. Entrepreneurship and Regional Development, 28, pp.724-745.

[41] Shane, S.A., (2004). Academic entrepreneurship: University spinoffs and wealth creation. Edward Elgar Publishing. 
[42] Soetanto, D., \& Geenhuizen, M. (2015). Getting the right balance: University networks 'influence on spin-offs' attraction of funding for innovation, Technovation, 36-37, Elsevier Ltd, pp.26-38, DOI:

[43] Stam, E. (2015). Entrepreneurial ecosystems and regional policy: a sympathetic critique. European Planning Studies, 23 (9), pp.1759-1769.

[44] Statistical Office of the Republic of Serbia (2018). Statistical Yearbook of the Republic of Serbia. Retrieved from: http://www.stat.gov.rs/sr-Latn/oblasti/strukturne-poslovne-statistike/godisnji-kazateljiposlovanja-preduzeca.

[45] Statista. (2018). Serbia: Unemployment rate from 2007 to 2017. Retrieved from: https://www.statista.com/statistics/440532/unemployment-rate-in-serbia/.

[46] Steffensen, M., Rogers, E. M., \& Speakman, K. (2000). Spin-offs from research centers at a research university. Journal of business venturing, 15(1), pp.93-111.

[47] Suresh, J., \& Ramraj, R. (2012). Entrepreneurial ecosystem: Case study on the influence of environmental factors on entrepreneurial success. European Journal of Business and Management, 4(16), pp.95-101.

[48] Spigel, B (2017). The Relational Organization of Entrepreneurial Ecosystems, ENTREPRENEURSHIP THEORY and PRACTICE 49, DOI: 10.1111/etap.12167.

[49] Todorovic, Z., McNaughton, R., Guild, P., ENTRE-U: An entrepreneurial orientation scale for universities". Technovation, Vol.31, (2011), pp.128-137.

[50] Trading Economics (2018). Serbia GDP. Retrieved from: https://tradingeconomics.com/serbia/gdp.

[51] University of Novi Sad (2018). Retrieved from: www.uns.ac.rs.

[52] Van Geenhuizen, M., \& Soetanto, D. P. (2009). Academic spin-offs at different ages: A case study in search of key obstacles to growth. Technovation, 29(10), pp.671-681.

[53] Vekic, A., Borocki, J.,Ciric, D., \& Djercan, B. (2018). Uloga univerziteta u razvoju inovacija i preduzetništva u Republici Srbiji, XXIV Skup TRENDOVI RAZVOJA: "DIGITALIZACIJA VISOKOG OBRAZOVANJA", Kopaonik, 21. - 23. 02. 2018.

[54] Vogel, P. (2013a). Building and evaluating entrepreneurial ecosystems. Presentation to OECD LEED Program Workshop on Entrepreneurial Ecosystems and Growth-Oriented Enterprise, The Hague, 7 November.

[55] Vogel, P (2013b). The employment outlook for youth: building entrepreneurial ecosystems as a way forward. An essay for the G20 Youth Forum 2013, St Petersburg, Russia.

[56] Walter, A., Auer, M., \& Ritter, T. (2006). The impact of network capabilities and entrepreneurial orientation on university spin-off performance. Journal of business venturing, 21(4), pp.541-567.

[57] Yan,Y., \& Guan, J. (2018). "Entrepreneurial ecosystem, entrepreneurial rate and innovation: the moderating role of Internet attention. International Entrepreneurship and Management Journal, Springer Science + Business Media, LLC, part of Springer Nature 2018. DOI: 10.1007/s11365-018-0493-8

Received: 2018-09-29

Revision requested: 2019-02-03

Revised: 2019-02-26

Accepted: 2019-03-12

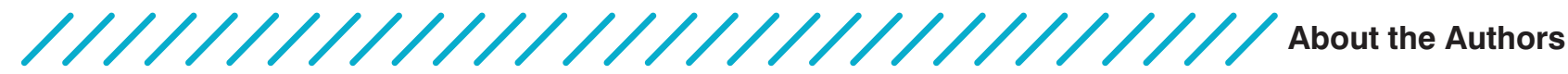

Aleksandar Vekić

University of Novi Sad, Faculty of Technical Science, Department of Industrial Engineering and Management,Serbia vekic@uns.ac.rs

Aleksandar Vekić, MSc, works as a teaching assistant at the University of Novi Sad, Faculty of Technical Sciences, Department of Industrial Engineering and Management. $\mathrm{He}$ is currently enrolled in $\mathrm{PhD}$ studies - Inovation and Entrepreneuership. His research and teaching area of interest includes Entrepreneuership, Innovation Management, Sustainable SMEs Development, Entrepreneurial Strategies, Entrepreneuership in High Technology, Development Processes in Company.

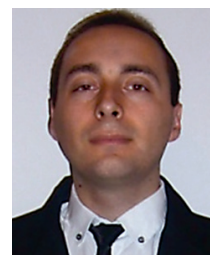




\section{Angela Fajsi \\ University of Novi Sad, Faculty of Technical Sciences, Serbia angela.fajsi@uns.ac.rs}

Angela Fajsi is a Teaching assistant at Faculty of Technical Sciences, University of Novi Sad. She earned her master's degree in Industrial engineering and management at the same faculty. Angela gained significant experience in projects that support SMEs in improving their performance and increasing their competitiveness. Her main interests are in industrial clusters, value networks and project management.

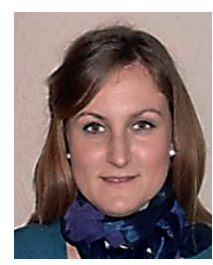

Jelena Borocki University of Novi Sad, Faculty of Technical Science, Department of Industrial Engineering and Management,Serbia borocki@uns.ac.rs

Jelena Borocki is an Associate Professor of Entrepreneurship and Innovation Management. Besides her experience at the faculty, she has more than 20 years of experience as a consultant for SMEs in the area of starting a new business, innovation management and strategic entrepreneurship. In the field of entrepreneurship and innovation management (which are her areas of expertise) she specialized in USA, Italy and Germany. She is a project advisor on few European projects (Horizon 2020, TEMPUS, IPA, CIP), as well as on a number of projects financed and supported by The Ministry of Education, Science and Technological Development of the Republic of Serbia (Best Technology Innovation Competition and two other national projects). She published one book and more than 50 scientific papers. 